\title{
The intensity of symbiotic relationships between arbuscular mycorrhizae and differentiated tree species regarding their age group and plant family in semi-arid Andine dynamical agroforestry system.
}

Abstract: As research on mycorrhiza progress and scientific knowledge about organic partnerships becomes more profound, mycorrhiza symbiosis is considered an essential parameter for the vitality of ecosystems. Concerning polyculture cultivation systems, the implementation of growth-promoting and nutrient-securing symbiotic partners is a crucial step towards preserving the dynamism of involved plants and thus decisive for the yield and success of such cultivation systems. In particular, arbuscular mycorrhizal fungi (AMF) show considerable tendency in encouraging and maintaining a supply of water and nutrition for plants. Therefore, it was examined how intensive partnerships between AMF and trees in the semi-arid, dynamic agroforestry system of 'Mollesnejta' exist and how the species, family and age of trees are related to the respective degree of mycorrhizal intensity. This information is in turn used to decrypt relationships between nutrient provision and nutrient security in agroforestry systems and to improve them especially concerning current climate change. The results reveal that in the examined agroforestry system arbuscular mycorrhizal partnerships were found on all ten considered tree species in this study in varying intensity of the mycorrhizal structure dependent on tree species and their plant family. Nevertheless, no statistical correlation between the number of mycorrhizal elements according to primary hyphae, ramification or vesicles about the age of the trees could be proven in this study.

KeyWords: Age group, agroforestry, arbuscular mycorrhizae, semi-arid, subtropics.

\section{Introduction}

\section{Role of Arbuscular Mycorrhiza in Ecosystems}

Plants are autotrophic organisms capable of synthesizing all their components from water, carbon dioxide, and mineral elements with photosynthetic radiation. Studies of plant nutrition have shown that specific mineral elements are essential to ensure their growth and health¹. To guarantee optimal nutrition sustenance, land plant evolution began to develop their nutritional mineral input at least 400 million years ago in symbiosis with mycorrhizal fungi, especially AMF of which approximately 150 - 200 species inside the family Glomeromycota exist ${ }^{2}$. The small number of AMF species might suggest their role in enriching biodiversity is limited, but the variations on their physiologic, morphologic, and genetic levels are rather high, resulting in a robust functional diversity that has a significant impact on ecology and application in plant production systems ${ }^{3}$. So far, the AMF association with terrestrial plants has been observed in 200 families of plants representing circa 1.000 genera and at least 300.000 species $^{4}$. Therefore, mycorrhizal fungi, mainly AMF are ubiquitous in soil and create associations with most herbaceous angiosperms including many crops, cereals, vegetables, trees and horticultural plants ${ }^{5,6}$ The fine fungal hyphae with size of $2-12 \mu \mathrm{m}$ radiating from the mycorrhiza increase the contact surface of the root with the soil 7 . After mycorrhizal infection roots by AMF's fine hyphae and the following extension of the plant's roots system facilitates the acquisition of water and mineral elements i.e. phosphorus that is relatively immobile in the soil and nutrients such as nitrogen, zinc, and copper. In return, plants provide carbohydrates ${ }^{8}$ and lipids ${ }^{9}$ to the arbuscular mycorrhizae. Likewise AMF stimulates the production of growth substances and may reduce stresses, diseases or pest attack ${ }^{10}$. AMF occurs over a global range of agro-climatic conditions in natural and agricultural ecosystems and is geographically ubiquitous ${ }^{11}$. Nevertheless, terms of the soil such as erosion, salinity, waterlogging, water holding capacity, soil types, soil porosity, fertility status, and vegetation, etc. appreciably influence AMF associations, composition, distribution, and activity ${ }^{12}$. Optimization and improvement of mycorrhizal symbiosis for different "agricultural applications can be considered as the attempt to extract the maximum plant benefit from colonization for the minimum loss of resources"13. \section{Improvement of Agroforestry Systems by Arbuscular
Mycorrhizae}

The intensification of agriculture as an inescapable consequence of the constraint to produce foodstuffs compounded with fast and uncontrolled industrialization has put an enormous burden on the natural ecosystem ${ }^{3}$. Agricultural impacts on biological, physical and chemical attributes of soils and their ecosystems, leading to biodiversity losses, decreases in soil coverage, changes in natural element cycles and the overall water balance, degradation of soil structure, erosion and contamination of groundwater and therefore resulting in unknown consequences of high complexity ${ }^{14,15}$. Considering the current cultivation methods, there is an increasing interest in agroforestry systems. Agroforestry is defined by growing trees along with various types of crops to enhance crop yields, conserve soil and recycle nutrients while producing fodder, fruit, timber, and wood for non-corporate and economic use ${ }^{16}$. Under agroforestry, the needs for ecological sustainability can be reconciled with the needs and future challenges for sustainable food production ${ }^{17}$. To ensure plant nutrition in such cultivation systems, it is crucial to understand the interactions among the

Student of Phytotechnology in Horticulture, Beuth University of Applied Science, Berlin, Germany.

${ }^{2}$ Lab. De Chagas e Inmunoparasitologia-Depto. De Biologia- Fac. de Ciencias y Tecnologia-Univ Mayor de San Simon, Cochabamba, Bolivia.

${ }^{3}$ Mollesnejta - Andean Agroforestry Center, Cochabamba-Bolivia. 
actors and to improve plant growth by enhancing measures.

Consequently, AMF has associated with improved and enhanced growth of many plant species due to production of growth-promoting substances and synergetic interactions with other beneficial and necessary microorganisms, thus affecting the whole ecosystem where AMF subsist ${ }^{18}$. In a study ${ }^{19}$ about subtropical agroforestry systems and the influence of mycorrhiza, 93 of the 101 tree species evaluated inside the agroforestry system were colonized by AMF. The general soil conditions prevalent in sustainable agriculture equivalent dynamic agroforestry are likely to be more beneficial to AMF than those under conventional agricultural methods corresponding pesticide application, fertilization and tillage ${ }^{5,20}$. Under nutrient saturating conditions related to high-input agrarian systems, the considerable advantages are reduced while the carbohydrates costs for the plant remain, and the overall performance, including yield by AMF colonized plants can fall below that of those that are non-colonized ${ }^{21}$. Since the mycorrhizal association may shift from a symbiotic relationship to a parasitic and damaging association because the fungus still obtains carbohydrates from the infected plant, but the host plant no longer benefits from improved nutrient uptake efficiency ${ }^{22,23}$. AMF may provide a more appropriate and environmentally acceptable alternative for sustainable agriculture including agroforestry, due to the fact of increasing expenses of inorganic fertilizers by agrochemical industry as well as environmental and public hazards associated with pesticides and following the pathogens resistant to chemical pesticides ${ }^{24}$. Therefore, it was examined how intensive the potential partnerships between AMF and trees in a semi-arid, dynamic agroforestry system develop and how the tree species plus their plant-family and age of the trees are related to the degree of mycorrhizal intensity. This information is necessary to decrypt the relationships between nutrient provision and nutrient security in agroforestry systems and to improve them under adverse conditions, especially about current climate change and their resulting extreme conditions. Unfortunately, studies examining arbuscular mycorrhizal colonization not only with individual tree species but in a complete agroforestry system are scarce ${ }^{25}$.

\section{Materials and methods}

\section{Climate and Soil Conditions}

The degree of mycorrhizal colonization was analyzed in ten different tree species on the 16 ha agroforestry area in Mollesnejta at 2750 to 2840 meters above sea level beginning of May 2019. The research institute is located near the Andes border in the center of Bolivia in the proximity of Cochabamba. The study was performed during dry period southern of equator, and due to the winter season, the daylight was decreasing. Because of its altitude above sea level, the subtropical area is in the USDA winter hardiness zone 10a and can, therefore, reach absolute minimum temperatures of $-1.1{ }^{\circ} \mathrm{C}$ at night ${ }^{26}$. The average annual temperature is $16.5^{\circ} \mathrm{C}$, showing respectively a minimum average temperature of $8.7^{\circ} \mathrm{C}$ and a maximum average temperature of $25.4^{\circ} \mathrm{C}$. The middle yearly precipitation is $518 \mathrm{~mm}$, of which only $68 \mathrm{~mm}$ in sum are precipitated during the seven arid months of April, May, June, July, August, September, and October. The soil profile of the agroforestry landscape was very nutrient-poor, had a high sand content and contained a high amount of unweathered Andean rocks. The phosphorus content available to the plants and salt conductivity of the soil amounted on average of only $9.339 \mathrm{kgP}_{2} \mathrm{O}_{5} / \mathrm{ha}$ as well as an electric salt conductivity of only $0.27 \mathrm{mS} / \mathrm{cm}$ at the start of the experiment. The $\mathrm{PH}$ value of 5.3 proved slightly acidic. There was generally a very thin or almost nonexistent layer of humus, as large parts of the terrain were destroyed 19 months before the start of the test due to a massive area fire. As a result, the upper humus layer was partially burnt, and therefore soil fertility was reduced. Nevertheless, the soil directly around the trunks of the trees had higher humus content and more excellent aggregate stability than the rest of the surrounding fallow land.

\section{Biological Materials and their Preparation}

To analyze the degree of mycorrhizal colonization, three trees per tree species of Inga feuillei, Caesalpinia spinosa, Erythrina falcata, Acacia visco, Tecoma stans, Tecoma cochabambensis, Jacaranda mimosifolia, Fraxinus americanus, Zanthoxylum coco and Schinus molle in the age classes 5, 10 and 15-20 years were examined. An exception was made for Acacia visco, as only three 10-year-old trees were available during the time of this experiment. Before sampling, the trees were surveyed for external conspicuities such as the influence of biotic and abiotic damage. All trees were externally vital at the time of sampling and showed no abnormalities except of exfoliation due to the current dry winter season. Three excavations were carried out at angles of $120^{\circ}$ a depth of $30 \mathrm{~cm}$. Several samples were taken per excavation consisting in sum of at least four light-colored fine-root strands, with a minimum length of $2 \mathrm{~cm}$ each. Furthermore, focus was to examine trees with the same soil samples in order to maintain comparability of the results and limit additional interrelations. Subsequently, the mycorrhiza was stained according to the method of Ungar et al. ${ }^{27}$, which represents a slightly modified form of the established methodology of Vierheilig28. At first, the root cells were discolored by destroying their cytoplasm in a process of heating them for 10 minutes in a solution of $10 \%$ potassium hydroxide $(\mathrm{KOH})$, then hyphae were colored with black ink (Brand: Pelikan) by heating in a $5 \%$ vinegar solution in ratio of 1:50 for 3 minutes. The samples were then stored in a $50 \%$ water-alcohol solution. From each pack of excavated root sample, two different fine-root strands were chosen randomly and observed under the microscope. Collectively, 180 root samples were evaluated, including 18 samples per tree species and six samples per tree and for its respective age. The absolute number of all stained mycorrhiza elements such as main hyphae, ramifications/ branches and vesicles were counted under microscope under tenfold magnification, insofar as these could be identified after the mentioned staining methods. After that, the total number of each mycorrhizal element was counted on the planar upper root area. Due to strong varying visibility of arbuscles, dependent upon tree, AMF species, and other factors, the arbuscles were not observed in order to allow a direct comparison with other tree species and their age groups. The absolute area of each examined root sample was determined photometrically using a 12-megapixel color camera at a $90^{\circ}$ angle to the root samples and Image J software Version 1.52a (Publisher: Wayne Rasband, National Institutes of Health, USA). For this purpose, the percentage background of the root sample ) was calculated by binary reduction (black, white) of the image and its relative proportion was subtracted from the total area of the object slide () to obtain the entire roof area in square millimeters and to calculate the number of mycorrhizal elements per one square millimeter root area ( The Mathematical calculation for the degree of mycorrhizal colonization is noted below: 


$$
M D\left[\frac{x}{m m^{2}}\right]=\frac{n_{E}[x]}{(1-B \mid N[\%]) \cdot A_{t o t}\left[m m^{2}\right]}
$$

$M D$ : Degree of mycorrhizal colonization [Quantity $/ \mathrm{mm}^{2}$ ]

$n_{E}$ : Quantity of mycorrhizal element $[\mathrm{x}]$

$B_{N}$ : Relative amount of negative binary background [\%]

$A_{\text {tot }}$ : Total area of object slide $\left[\bumpeq 324 \mathrm{~mm}^{2}\right]$

\section{Statistical Analysis}

The non-parametric Kruskal-Wallis test $(\alpha=0.05)$ was performed, to prove potential differences between the age groups and the proportion of hyphae elements. Since the dependent variable "age" was not normally distributed, the lowest distribution was ordinarily scaled, and the samples were independent of each other. Due to the sample size of 180 $>30$ (critical value), the asymptotic significance value was taken into consideration. Based on the small sample size for trees 15 and 20 years old, these were grouped as category "15-20". The relationship between the relative proportion of

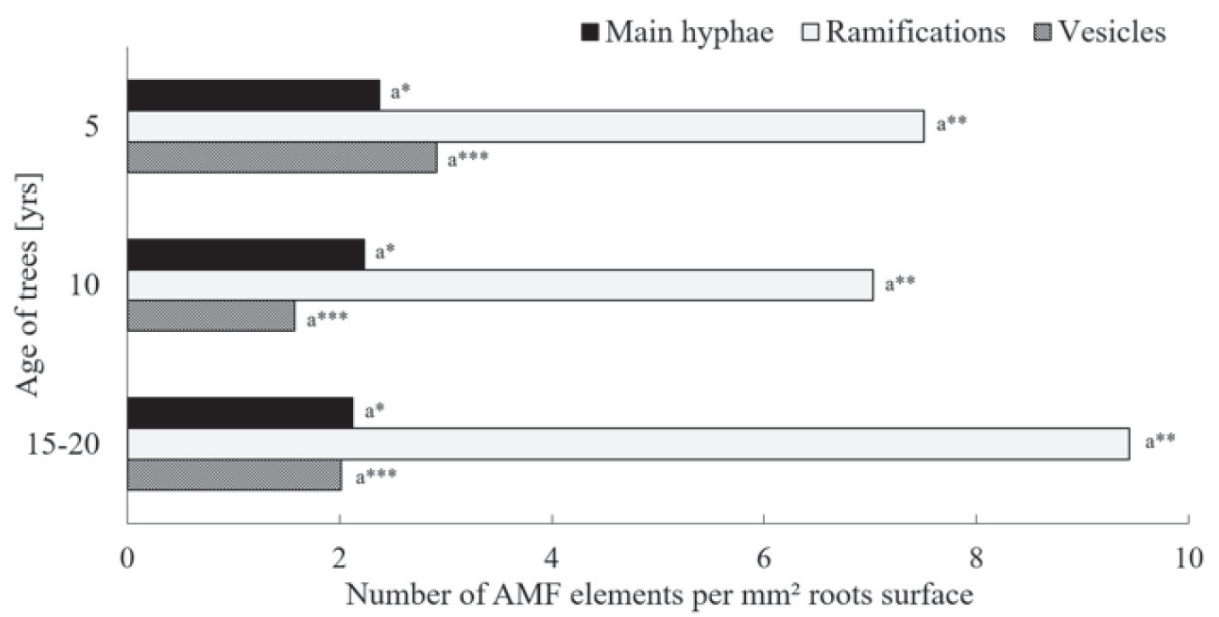

Figure 1. Degree of mycorrhizal growth of all investigated tree species depending on their age examined in Andean agroforestry Mollesnejta during arid dry-season. Toe relevant AMF elements were main hyphae, ramifications, and vesicles. Statistical test with Kruskal-Wallis $\backslash \cdot 1$ lethod and $\alpha=0.05$. Due to $p=0,488>0,05^{\star}, p=0,388>0,05^{\star *}$ and $p=0,417>0,05^{\star * *}$ a coherence between tree age and number of each mycorrhizal element could not be couriered.

- Total number of AMF elements $\square$ Proportion of root samples with AMF [\%]

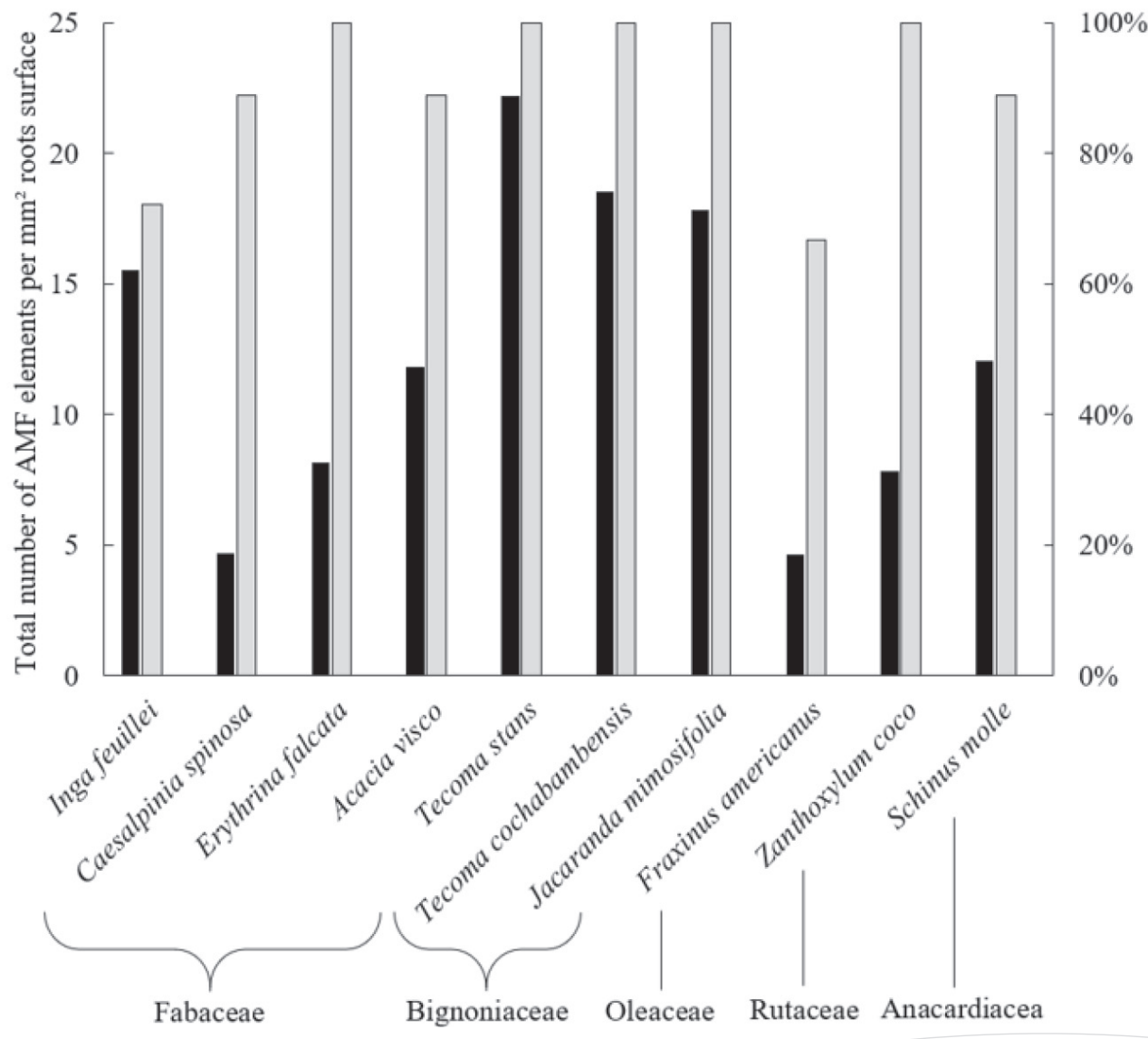

Figure 2. Comparison of absolute arbuscular mycorrhizalization and H the relative proportion of $\sum_{4}$ trees with arbuscular myE corrhizal fungi depending on tree species and their \& plant families investigated in the Andean agrofo范 restry Mollesnejta during " arid dry season. Elements of AMF were the sum of primary hyphae, branches, and vesicles. The relationship between the total number of mycorrhiza elements and the relative proportion of trees infected with mycorrhiza was tested with Pearson Chi-square and. $=0.05$. Based on $p=$ $0,314>0,05$, the relation between the number of counted AMF elements and the relative proportion of AlMF infected trees could be excluded. 

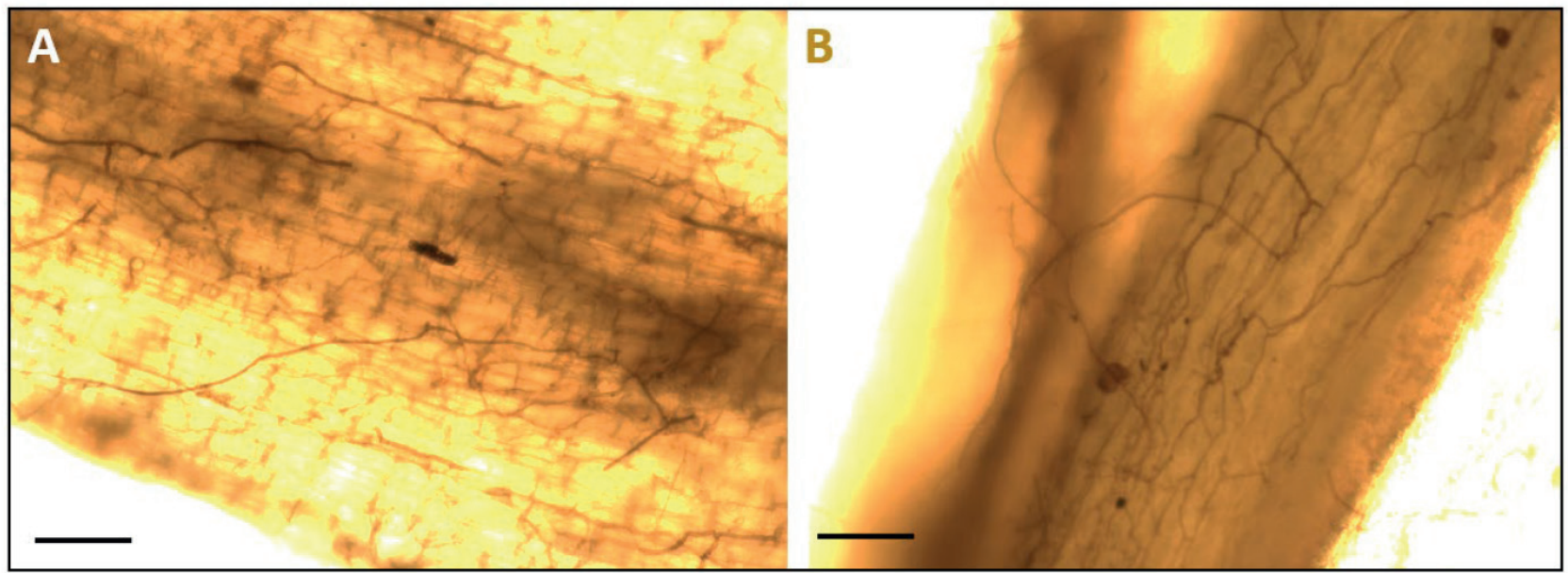

Figure 3. Hyphal structure of arbuscular mycorrhizae on the fine root strands of (A) Tecoma stans (15 yrs. old) and (B) Schinus molle (10 yrs. old). Black bar equals $60 \mathrm{tm}$.

trees infected with mycorrhiza compared to the intensity of mycorrhizae regarding the tree species was analyzed by using the Pearson Chi-square test $(\alpha=0.05)$ due to nominal scaled parameter of the lowest test variable. All statistical analyses were performed using the open-source software PSPP Version 3.0 (Publisher: Benn Pfaff) under GNU General Public License.

\section{Results and Discussion}

The results showed that AMF is omnipresent in the root structures of the studied agroforestry system and are in symbiosis with all observed tree species regardless of age (Figure 1 and 2). The findings confirm other investigations ${ }^{29,30}$ that mycorrhiza plays a fundamental role in balancing agrosystems and represent an essential link between soil and root. The positive effects on nutrient supply and water transfer as well as the general significance of AMF for ecosystems as already described in various literature ${ }^{31-35}$ confirm the high occurrence of arbuscular mycorrhizae in this experiment (Figure 1 and 2) respective to the overall vital health of the trees. The thesis that acidic to neutral soils containing a large number of AM fung $i^{3}$ could be confirmed by the average $\mathrm{PH}$ value of 5.3 on the areal and the widespread colonization by AMF (Figure 2). Because of the plural anastomosing mycorrhiza net ${ }^{37}$, plants of different species can exchange substances and communicate among themselves with organic carbon compounds ${ }^{38,39,40}$, which can be anticipated based on the uniformly mycorrhization of all examined trees, impartial with respect to their species, plant family (Figure 2) or age (Figure 1).

However, no statistical correlation between the intensity of mycorrhizal growth and age could be established by this experiment (Figure 1). Due to strong scattering of the determined values regarding primary hyphae, ramifications and vesicles, the Kruskal-Wallis test showed no correlation between the two parameters. Only the branching seems to have cumulated slightly, which could be explained by the colonization of further species of mycorrhiza with increasing age of the trees ${ }^{41}$. The difference of the ramifications between the 10 and 15 to 20-year-old trees was determined by a separate Kruskal-Wallis test, but also here the results of $p=0.203$ over $\alpha=0.05$, and no difference between the two test factors could be confirmed. Indeed there were differences in the absolute number of mycorrhizal elements in the studied tree species (Figure 2).

In such cases, differences could be observed regarding the tree species and their plant families. On all plant species of the
Bignoniaceae family, 100\% of the samples were colonized by arbuscular mycorrhizae, which corresponds to other scientific results ${ }^{19,42,43}$. In comparison to the other examined tree species, Bignoniaceae proved to contain the highest intensity of mycorrhizae elements (Figure 2). On the other hand, the Fabaceae plant family showed significantly lower colonization of AMF in the root cells, while retaining a high proportion of positive colonized samples. This difference between the plant families could be due to the ability of the plant to regulate the overall colonization level, based on altering plant-available nutrition value in the soil 44,45 or to guarantee an economic output of it's own assimilates ${ }^{46}$.

Nevertheless, such assumptions must be confirmed by further investigation upon said tree samples. Predominant and extremely aversive abiotic stressors make the growth and survival of plants more difficult ${ }^{47}$, especially as the general low nutrient conditions with an electrical salt conductivity of only 0.27 , the seven arid months and the resulting drought stress, as well as the high temperatures during the day in the sun in this case. Since all plants had a vital state of health, the colonization of tree roots by AMF with its water and nutrient-enriching attributes must be considered as a defense against abiotic stressors $5,48,49,50,51$.

Phosphate is an essential nutrient and limits plant grow$t^{52}$. Because of the low $\mathrm{P}_{2} \mathrm{O}_{5}$ content of $9.339 \mathrm{~kg} / \mathrm{ha}$ other relevant vectors must introduce phosphorus into the soil or make the current organic phosphorus available to the plants, otherwise sufficient growth of the trees would not be possible. Mycorrhizal fungi have been shown to mineralize organic soil phosphate through the synthesis of phosphatase ${ }^{53,54}$. Similar to phosphate, nitrogen is a major limiting nutrient to plant grow$\mathrm{th}^{13}$, and most of the nitrogen in the soil is only available as ammonium $\left(\mathrm{NH}_{4+}\right)$ or nitrate $\left(\mathrm{NO}_{3}\right)$. Ammonium is the preferential form of nitrogen absorbed by subjected to a nitrogen deficiency $^{55,56}$, but its concentration is $10-1000$ times lower than of nitrate, especially in acidic soils like in this experiment ${ }^{23}$. Ammonium has minimal mobility in the soil and similar to phosphate, a zone of depletion is formed around the roots. AMF extraradical mycelium can absorb ammonium ${ }^{57,58,59}$, nitrate $^{58}$ and amino acids ${ }^{60}$. It can, therefore, be assumed that the colonization of all tree species by AMF (Figure 2), regardless of the age of the trees (Figure 1), is associated with the compulsion for the plant to obtain nutrients from the soil and thus to enter into a symbiosis with the fungi. 


\section{Conclusions}

The intensity of mycorrhizal variation across all investigated parameters did not differ between the three age groups. The results indicate that in nutrient-limited, semi-arid, subtropical, dynamic agroforestry systems arbuscular mycorrhizae are present in symbiosis with all ten examined tree species in the varying intensity of fungal hyphae structure. Furthermore, it would be interesting to decipher the species of the current AMF by protein sequencing and to investigate which species are beneficial for agroforestry systems concerning growth, age of trees and climatic seasons.

\section{Bibliographic references}

1. White J. P. (2012): Ion Uptake Mechanisms of Individual Cells and Roots: Short-distance Transport. In: Marschner's Mineral Nutrition of higher Plants. Elsevier Ltd., Chennai, India. 33.

2. Remy W., T. N. Taylor, H. Hass, H. Kerp (1994): Four hundred-million-year-old vesicular arbuscular mycorrhizae. Proceedings of the National Academy of Sciences, USA. 91. 11841-11843.

3. Panwar J., R. S. Yadav, B. K. Yadav, J. C. Tarafdar (2008): Arbuscular Mycorrhizae - A Dynamic Microsymbiont for sustainable Agriculture. Springer Science, Aligarh, India. 160, 163, 165.

4. Bagyaraj D. J. (1991): Ecology of vesicular arbuscular mycorrhizae. In: Handbook of Applied Mycology Vol. I, eds., Arora, D. K., Rai, B., Mukerji, K. G., and Knudsen, G. R., Marcel Dekker, New York. 3-34.

5. Smith S. E., D. J. Read, J. L. Harley (1997): Mycorrhizal Symbiosis. Academic Press, San Diego, CA, USA. 26, 622.

6. Siddiqui Z. A. and J. Pichtel (2008): Mycorrhizae - An Overview. Springer Science, Aligarh, India. 11.

7. Kandeler E. (2010): Bodenorganismen und Ihr Lebensraum. In: Scheffer / Schachtschabel: Lehrbuch der Bodenkunde. Springer Spektrum-Verlag, Berlin-Heidelberg, Germany. 98-99.

8. Taiz L. and E. Zeiger (2001): Plant Physiology - Mineral Nutrition. Sinauer Associates Inc., Sunderland Massachusetts, USA. 84.

9. Keymer A., P. Pimprikar, V. Wewer, C. Huber, M. Brands, S. L. Bucerius, P.-M. Delaux, V. Klingl, E. von Röpenack-Lahaye, T. L. Wang, W. Eisenreich, P. Dörmann, M. Parniske, C. Gutjahr (2017): Lipid transfer from plants to arbuscular mycorrhiza fungi. eLife 2017; e29107; 6: 1-33.

10. Davet P. (1996): Vie microbienne du sol et production végétale. Paris: INRA.

11. Brundrett M.C. (2002): Coevolution of roots and mycorrhizas of land plants. New Phytol. 154: 275-304.

12. Manoharachary C. (2004): Biodiversity, taxonomy, ecology, conservation and biotechnology of arbuscular mycorrhizal fungi. Indian Phytopath. 57. 1-6.

13. Sawers R., S. Yang, C. Gutjahr, U. Paszkowski (2008): The Molecular Components of Nutrient Exchange in Arbuscular Mycorrhizal Interactions. Springer Science, Aligarh, India. 45, 163.

14. Tilman D. et al. (2001): Forecasting agriculturally driven global environmental change. Science 292: 281-284.

15. Foley J. A. et al. (2005): Global consequences of land use. Science 309: 570-574.

16. Sanchez P. A. (1995): Science in Agroforestry. Kluwer Academic Publishers Netherlands, Agroforestry Systems, 30, 5-55.

17. Young A. (1997): Agroforestry for soil management, 2nd edn. ICRAF and CAB International, Wallingford. 207-210.

18. Sreenivasa M. N. and D. J. Bagyaraj (1989): Use of pesticides for mass production of vesicular-arbuscular mycorrhizal inoculum. Plant Soil 119: 127-132.

19. Carneiro M. A. C., J. O. Siqueira, F. M. Moreira, D. Carvalho, A. S. Botelho, O. J. Saggin-Junior (1998): Micorriza arbuscular em espe'cies arbo'reas e arbustivas nativas de ocorrencia no Sudoeste do Brasil. Cerne 41: 129-145.
20.Bethlenfalvay G. J. and H. Schuepp (1994): Arbuscular mycorrhizas and Agrosystem stability. In: Impact of Arbuscular Mycorrhizas on Sustainable Agriculture and Natural. Ecosystems, eds., S. Gianinazzi, and H. Schuepp, Birkhäuser Verlag, Basel, Switzerland. 117-131.

21. Janos D. P. (2007): Plant responsiveness to mycorrhizas differs from dependence upon mycorrhizas. Mycorrhiza 17: 75-91.

22. Brundrett M. C. (1991): Mycorrhizas in natural ecosystems. Adv. Ecol. Res. 21: 171-313.

23. Marschner H. (1995): Mineral Nutrition of Higher Plants, 2nd ed. Academic Press, London. 16-19.

24. Akhtar M. S. and A. S. Zaki (2008): Arbuscular Mycorrhizal Fungi as Potential Bioprotectants against Plant Pathogens. Springer Science, Aligarh, India. 63.

25. Pande M. and J. C. Tarafdar (2004): Arbuscular mycorrhizal fungal diversity in neem-based agroforestry systems in Rajasthan. Appl Soil Ecol. 26: 233-241.

26. Heinze W. and D. Schreiber (1984): Eine neue Kartierung der Winterhärtezonen für Gehölze in Mitteleuropa. Mitteilungen der Deutschen Dendrologischen Gesellschaft

27. Ungar B., J. Vögerl, N. Medrano- Mercado, N. Stadler-Kaulich (2019): The importance of mycorrhiza in agroforestry systems for the stability of ecosystems in semi-arid zones and simple quantification of soil fungi - A study at the Mollesnejta research center for Andean Agroforestry in the valley of Cochabamba, Bolivia. Bionatura Conference Series. Revista Bionatura, Ibarra, Humboldt Kolleg Ecuador 2019, 22.02.-24.02.2019, Bionatura Conference Series Vol. 2. No. 1. 2019.

28. Vierheilig H., A. P. Coughlan, U. Wyss, Y. Piché (1998): Ink and Vinegar, a Simple Staining Technique for Arbuscular-Mycorrhizal Fungi. Applied and Environment Microbiology. 64. 12.

29. Miller R. M. and J. D. Jastrow (1994): Vesicular-arbuscular mycorrhizae and biogeo-chemical cycling. In: Pfleger, F. L. and Lindermann, R. G. (Eds.), Mycorrhizae and Plant Health. APS, St. Paul, MN. 189-212.

30.Doran J. W. and D. M. Linn (1994): Microbial ecology of conservation management systems. In: Hatfield, J. L. and Stewart, B. A. (Eds.), Soil Biology: Effects on Soil Quality. Lewis, Boca Raton, FL. 1-57.

31. Allen M. F. (1991): The Ecology of Mycorrhizae. Cambridge University Press, New York. 184.

32. Eason W. R., E. I. Newman, P. N. Chuba (1991): Specificity of interplant cycling of phosphorus: The role of mycorrhizas. Plant Soil 137: 267-274.

33. Gupta R. K. (1991): Drought response in fungi and mycorrhizal plants. In: Arora, D. K., Rai, B., Mukerji, K. G., and Kundson, G. R. (Eds.) Handbook of Applied Microbiology. Vol. I, Soil and Plants. Dekker, New York. 55-75.

34.Mukerji S., K. G. Mukerji, D. K. Arora (1991): Ectomycorrhizae. In: Arora, D. K., Rai, B., Mukerji, K. G., and Kundson, G. R. (Eds.), Handbook of Applied Microbiology. Vol. I, Soil and Plants. Dekker, New York. 187-215.

35. Van der Heijden M. G. A., J. N. Klironomos, M. Ursic, P. Moutoglis, R. Streitwolf-Engel, T. A. Boller, A. Wiemken, I. R. Sanders (1998): Mycorrhizal fungal diversity determines plant biodiversity, ecosystem variability and productivity. Nature 396: 69-72.

36. Vogelsang K. M., H. L. Reynolds, J. D. Bever (2006): Mycorrhizal fungal identity and richness determine the diversity and productivity of tallgrass prairie system. New Phytol. 172: 554-562.

37. Giovannetti M., I. Avio, P. Fortuna, E. Pellegrino, C. Sbrana, P. Strani (2006): At the root of the Wood Wide Web. Self recognition and non-self incompatibility in mycorrhizal networks. Plant Signal. Behavior 1: 1-5.

38. Heap A. S. and E. I. Newman (1980): Links between roots by hyphae of vesicular-arbuscular mycorrhizae. New Phytol. 85: 169-171.

39. Egerton-Warburton L. M., J. I. Querejeta, M. F. Allen (2008): Efflux of hydraulically lifted water from mycorrhizal fungal hyphae during imposed drought. Plant Signal. Behav. 3: 68-71.

40.Lerat S., R. Gauci, J. G. Catford, H. Vierheilig, Y. Piche, L. Lapointe (2002): C-14 transfer between the spring ephemeral Erythronium americanum and sugar maple saplings via arbuscular mycorrhizal fungi in natural stands. Oecologia 132: 181-187. 
41. Visser S. (1995): Ectomycorrhizal fungal succession in jack pine stands following wildfire. New Phytologist. 129. 389 - 401.

42.Zangaro W., S. M. Nisizaki, J. C. Domingos, E. M. Nakano (2003): Mycorrhizal response and successional status in 80 woody species from south Brazil. J Trop Ecol. 19: 315-324.

43. Siqueira J. O. and O. Saggin Ju'nior (2001): Dependency on arbuscular mycorrhizal fungi and responsiveness of some Brazilian native woody species. Mycorrhiza 11: 245-255.

44.Braunberger P. G., M. H. Miller, R. L. Peterson (1991): Effect of phosphorous nutrition on morphological characteristics of vesicular-arbuscular mycorrhizal colonization of maize. New Phytol. 119: 107-113.

45. Kaeppler S.M., J. L. Parke, S. M. Mueller, L. Senior, C. Stuber, and W. F. Tracy (2000): Variation among maize inbred lines and detection of quantitative trait loci for growth at low phosphorous and responsiveness to arbuscular mycorrhizal fungi. Crop Sci. 40: 358-364.

46. Vierheilig H. (2004): Further root colonization by arbuscular mycorrhizal fungi in already mycorrhizal plants is suppressed after a critical level of root colonization. J. Plant Physiol. 161: 339-341.

47. Cramer G. R., K. Urano, S. Delrot, M. Pezzotti, K. Shinozaki (2011): Effects of abiotic stress on plants: a systems biology perspective. BMC Plant Biol. 2011; 11: 163.

48. Roesti D., K. Ineichen, O. Braissant, D. Redecker, A. Wiemken, M. Aragno (2005): Bacteria associated with spores of the arbuscular mycorrhizal fungi Glomus geosporum and Glomus constrictum. Appl. Environ. Microbiol. 71: 6673-6679.

49.Khan A.G. (2006): Mycorrhizoremediation - an enhanced form of phytoremediation. J. Zhejiang Univ. Sci. B. 7: 503-514.

50. Singh H. (2006): Mycorrhizal fungi in rhizosophere bioremediation. In: H. Singh (Ed.), Mycoremediation: Fungal bioremediation. John, New York. 533-572.

51. Martin F., S. Perotto, P. Bonfante (2007): Mycorrhizal fungi: A fungal community at the interface between soil and roots, pp. 201-236. In R. Pinton, Z. Varanini, and P. Nannipieri (Eds.), The rhizosphere: Biochemistry and organic substances at the soil plant interface. Marcel Dekker, New York.

52. Bucher M. (2007): Functional biology of plant phosphate uptake at root and mycorrhiza interfaces. New Phytol. 173: 11-26.

53. Dighton J. (1983): Phosphatase production by mycorrhizal fungi. Plant Soil 71: 455-462.

54. Tarafdar J.C. and H. Marschner (1994): Phosphatase activity in the rhizosphere and hyphosphere of VA mycorrhizal wheat supplied with inorganic and organic phosphorus. Soil Biol. Biochem. 26: 387-395.

55. Lee R. B. and K. A. Rudge (1986): Effects of nitrogen deficiency on the absorption of nitrate and ammonium by barley plants. Ann. Bot. 57: 471-486.

56. Gazzarrini S., L. Lejay, A. Gojon, O. Ninnemann, W. B. Frommer, N. von Wiren (1999): Three functional transporters for constitutive, diurnally regulated, and starvation-induced uptake of ammonium into Arabidopsis roots. Plant Cell 11: 937-948.

57. Johansen A., I. Jakobsen, E. S. Jensen (1992): Hyphal transport of $15 \mathrm{~N}$ labelled nitrogen by a vesicular-arbuscular mycorrhizal fungus and its effect on depletion of inorganic soil N. New Phytol. 122: 281-288.

58. Johansen A., R. D. Finlay, P. A. Olsson (1996): Nitrogen metabolism of the external hyphae of the arbuscular mycorrhizal fungus Glomus intraradices. New Phytol. 133: 705-712.

59. Johnson N., J. Graham, F. Smith (1997): Functioning of mycorrhizal associations along the mutualism-parasitism continuum. New Phytol. 135: 575-585

60. Hodge A., C. D. Campbell, A. H. Fitter (2001): An arbuscular mycorrhizal fungus accelerates decomposition and acquires nitrogen directly from organic material. Nature 413: 297-299.

Received: 11 October 2019

Accepted: 1 November 2019 